\title{
Quantitative biological data in Pliny's Naturalis Historia: a comparison of records of human strength, size and endurance in the classic Roman books, with modern Olympic records
}

\author{
Julián Monge-Nájera, Costa Rican Distance University, jmonge@ uned.ac.cr
}

\begin{abstract}
Roman author Pliny the Elder is mostly remembered for his book Natural History and for his death in AD 79, while observing the eruption of Vesuvius. For centuries, his book was read as fact, but problems detected in the $15^{\text {th }}$ century damaged its credibility, to the point that in the $20^{\text {th }}$ century it was seen as inspiration for fantastic fiction. However, in recent years, some experimental work has validated some previously rejected statements in Pliny's book. Here, I compare Pliny's claims about human strength, size and endurance and find that many of them are within the scope of modern Olympic records.
\end{abstract}

Keywords: Astomi, Cynocephalus, Gelada, Mythology, Pliny the Elder, Roman Natural History.

\section{Introduction}

Roman author Pliny the Elder is mostly remembered for his book Natural History and for his death in AD 79 while observing the eruption of Vesuvius at close quarters (Healy, 1999). For many centuries, the Natural History was considered a valid reference to natural phenomena, and over the centuries, importance was given to different topics, except, according to Casas (2008), for the pharmacopoeia, which was invariably a center of attention. In the late $15^{\text {th }}$ century, Niccolo Leoniceno noticed errors in some of Pliny's statements and started to doubt everything in the book; a debate followed about how much was Pliny's fault and how much the result of errors in translations and manuscript copying, but eventually this lead to an unfair and generalized rejection of Pliny's work (Healy, 1999), to the extreme that in the 20th century it was often seen as a collection of fantastic stories most suitable as inspiration for fictional literature (Casas, 2008; Gil Lascorz, 2015). More recent work shows a renewed interest in Pliny, including a revalidation of some of his work, mainly in crystallography, chemistry, and physics (Healy, 1999; Gibson \& Morello, 2011; Isager, 2013), but -as far as I could find- not in biology.

\section{Objective of this article}

Here I analyze 23 fantastic statements about humans in Pliny's Natural History and compare them with current medical knowledge about the human body, and with modern Olympic records

\section{Source}

I base my analysis of Pliny's Book 7, which deals with humans, on the English translation available online (Bostock \& Riley, 1855).

\section{Extremes of the human body}

Pliny also cites the Pygmies and the Trispithami, which are only $70 \mathrm{~cm}$ tall when adults. This is an exaggeration, because their real mean height is 155 centimeters for men and 147 for women (Migliano et al., 2013). 
Again, a background story is added to the original exaggeration: they are said to ride rams and goats and be at war with cranes, as told in the Iliad (B. iii. 1. 3-6). Pliny does not present many rules in his book, but he makes an exception for growth: humans reach half of their future height at the age of three, he says, which is basically correct according to modern pediatric data (Johns Hopkins University, 2020).

He also mentions a report that an earthquake in the island of Crete exposed bones of a giant, 21 meters in height. Crete has mammoth fossils (Poulakakis et al., 2002) and these fossils might have originated the story, but the Crete mammoth was a dwarf species and a size of 21 meters is a gross exaggeration. That size could more likely be miscalculated from remains of marine reptiles or dinosaurs, but I could not find any reports of such fossils from Crete.

Pliny presents several reports of very tall humans; Indians described by Onesicritus as 2,40 meters tall, Syrbotæ from Ethiopia 2,70 meters tall, and Gabbaras, a king from the time of Emperor Claudius, 2,86 metres tall. These reports are probably exaggerations, but still close to the known limits for human growth, as recorded for Robert Pershing Wadlow, who was 2,72 meters tall when he died in 1940. Pliny also mentions oversized children like Euthymenes of Salamis, who was $137 \mathrm{~cm}$ at the age of three, and adds the significant details that he was slow, mentally retarded and died young while suffering from convulsions. All of this is consistent with current medical knowledge, because human gigantism is caused by somatotroph pituitary adenomas and has all those symptoms (De Herder, 2004).

On the opposite extreme, Pliny mentions Conopas, who as an adult was only $69 \mathrm{~cm}$ in height, "a great pet with Julia, the grand- daughter of Augustus" and Andromeda, a woman of the same size. Again, this is consistent with current knowledge, the Nepalese Chandra Bahadur Dangi was 54.6 cm tall as an adult (Stulp \& Barrett, 2016).

He mentions triplets and quadruplets born in the Italian peninsula, and a report of septuplets from Egypt, according to Trogus, but while natural quadruplets are known, septuplets are only possible because of modern technology, according to scientific reports (Rosenthal, 2010; Connie, 2013).

He also mentions a woman, Eutychis of Tralles, who had 30 children; this is within possible female human fecundity (Gould \& Pyle, 2003). Pliny adds that in the times of Emperor Claudius, he himself saw a hippocentaur (human torso on a horse body) from Egypt, preserved in honey. Pliny was, in this case, a victim of a taxidermy hoax that was still operating nearly 20 centuries after him, with mermaids being the most common preserved fantastic chimaeras (Viscardi et al., 2014).

Pliny also mentions several cases of female children who turned male after their sexual development: "I myself saw in Africa one L. Cossicius, a citizen of Thysdris, who had been changed into a man the very day on which he was married to a husband". They could be real cases of Androgen Insensitivity Syndrome or hormonal imbalances caused by tumors (Norris \& Taylor, 1969; Nordt \& DiVasta, 2008).

\section{Feats of the human body that appeared fantastical but actually are within the known range of human variation}

For extremes of the human powers, he cites Crates of Pergamus for the statement that the Troglodytæ of Africa are able to outrun a horse, an apparently fantastical statement that recently has been shown to be real under 
appropriate circumstances (Halsey \& Bryce, 2020).

Pliny says that he once saw Athanatus, a strong man, "walk across the stage dragging weights of $660 \mathrm{~kg}$ in total". This is well under the current record for dragging a weight with wheels, as shown by Kevin Fast (www.guinnessworldrecords.com/worldrecords/heaviest-vehicle-pulled-over-100ftmale), so even though Athanatus did not use wheels in his act, this might be just an exaggeration of the real weight he could carry. Pliny cites Varro, about another strong man, Fusius, being able to carry a mule. This is improbable, but theoretically possible if the mule was small (under $300 \mathrm{~kg}$ ) and Fusius close to current Olympic records of quite briefly lifting 300 to 400 kilograms from the ground (Organising Committee for the Olympic Games, 2004).

For distance, Pliny cites runners able to travel $240 \mathrm{~km}$ in one day, which is practically impossible, the only similar report from recent times being an unconfirmed length of $560 \mathrm{~km}$ in over three days (Golub, 2006).

Regarding visual acuity and motor skill, Pliny mentions Callicrates and Myrmecides, who carved ants, chariots and ships the size of a fly; these are also within the possibilities of art today, even when done with minimal technological support (Yale University, 2008).

Pliny mentions that king Mithridates had a practical command of 22 languages; this is possible, albeit usually the number of languages is increased at the cost of real fluency (Fisher, 2018).

Maybe a more interesting case is his description of a person with savant syndrome, among the oldest, if not the oldest, in the literature. Pliny says that "there was in Greece a man named Charmidas, who, when a person asked him for any book in a library, could repeat it by heart, just as though he were reading". This ability, resulting from brain damage that reduces or destroys other facets of the human mind, is well documented and affects mostly men (Treffert, 2009).

He also mentions other effects of brain damage from disease or trauma, like forgetting the names of the alphabet letters or being unable to recognize particular people after head trauma; all of these are known effects according to modern medicine (Calabrese et al., 1995; Sacks, 2006).

\section{"Fantastic" peoples that match misinterpretations of known animals}

The entry that lead me to start this investigation was the fantastical description of a mountain tribe, the cynocephalus, where men bark, have the heads of dogs, and wear skins (Figure 1).

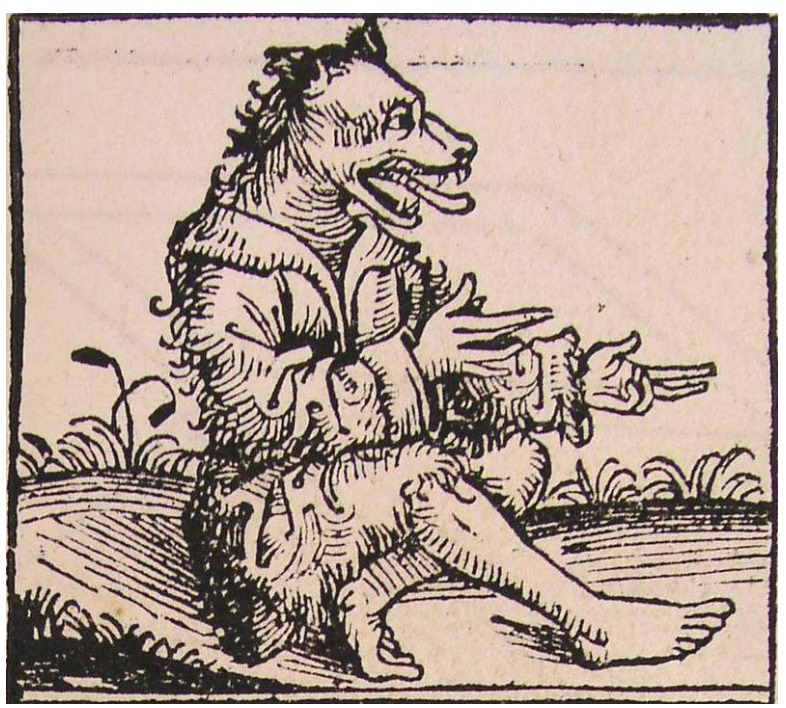

Figure 1. Pliny's cynocephalus tribe according to the Nuremberg Chronicle, by Hartmann Schedel (14401514): a dog-like head on a human-like body. https://en.wikipedia.org/wiki/Cynocephaly\#/media/Fi le:Schedel'sche_Weltchronik-Dog_head.jpg

This description reminded me of a scene in a BBC documentary about the geladas, 
Theropithecus gelada, of the Ethiopian highlands (Fashing et al., 2014) which, seen and heard from a distance, indeed fit the description (Figure 2).

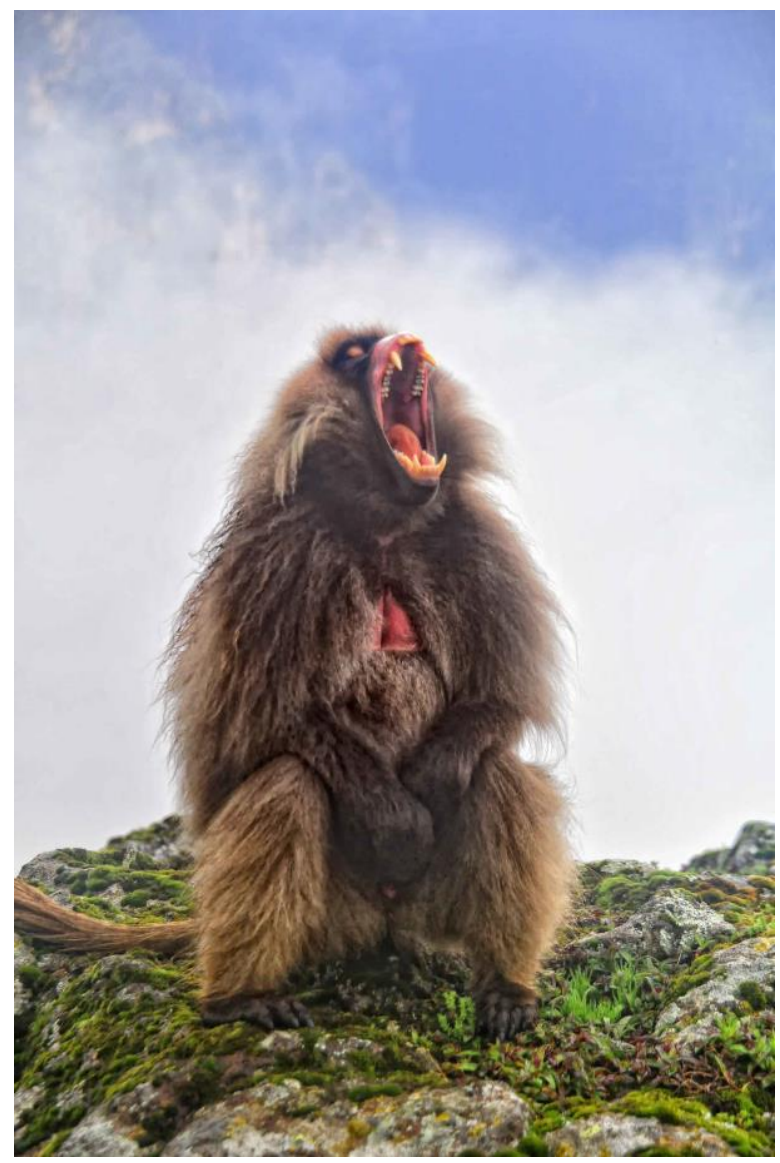

Figure 2. The gelada primate, Theropithecus gelada, from the mountains of Ethiopia, is phylogenetically related to humans, has an anthropomorphic body and a dog-like head; seen from a distance, its thick coat makes it look like a man wearing a fur. It might have originated the story of the dog headed tribe wearing furs. Photograph by Rod Waddington,

www.flickr.com/photos/rod waddington/619037563 3/in/photostream/ (CC BY-SA 2.0).

\section{"Fantastic peoples" that match exaggerations of known pathologies}

Pliny starts by reporting that, according to Herodotus and Aristeas of Proconnesus, the Arimaspi are born with only one eye in the middle of the forehead. That statement led to this representation in the Nuremberg Chronicle (Figure 3).

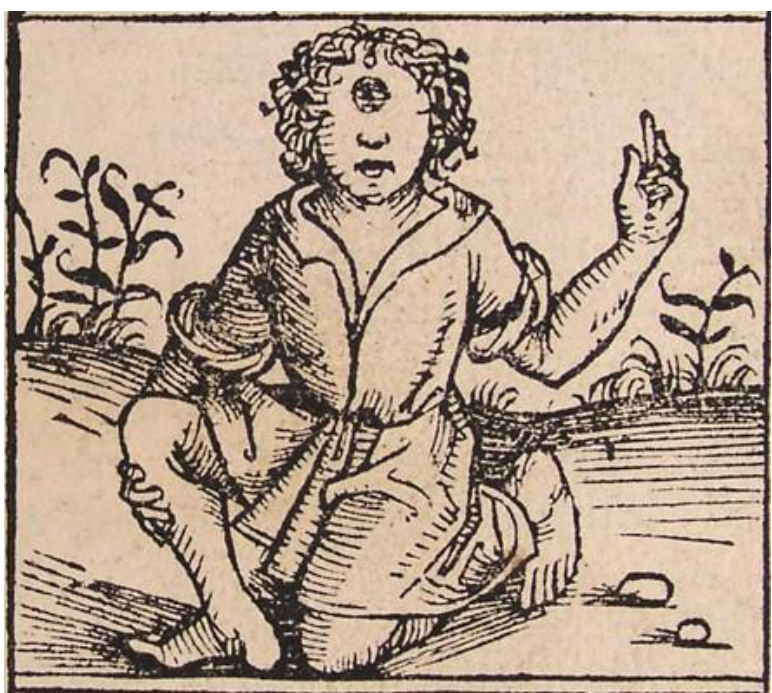

Figure 3. Pliny's Arimaspi according to the Nuremberg Chronicle, by Hartmann Schedel (14401514).

https://commons.wikimedia.org/wiki/File:Nuremberg chronicles - Strange People -

One Eye (XIIr).jpg

The Arimaspi could have been inspired by a real genetic abnormality called cyclopia, the details of which are described, for example, by Byrne et al. (1987). In my opinion, this is a good example of what seems to be a pattern in the Greek and Roman authors cited by Pliny, the exaggerated application of an individual abnormality to a whole people. I can imagine how the real story of a single child that was born with a genetic malformation, told over time, grows to become the fictitious story of a whole people having the malformation. To make it more appealing, the story becomes enriched with a whole background of additional stories. In the case of the one-eyed Arimaspi, further elaboration lead to the legend of them fighting griffins, as seen in this calyx-krater (Figure 4). 


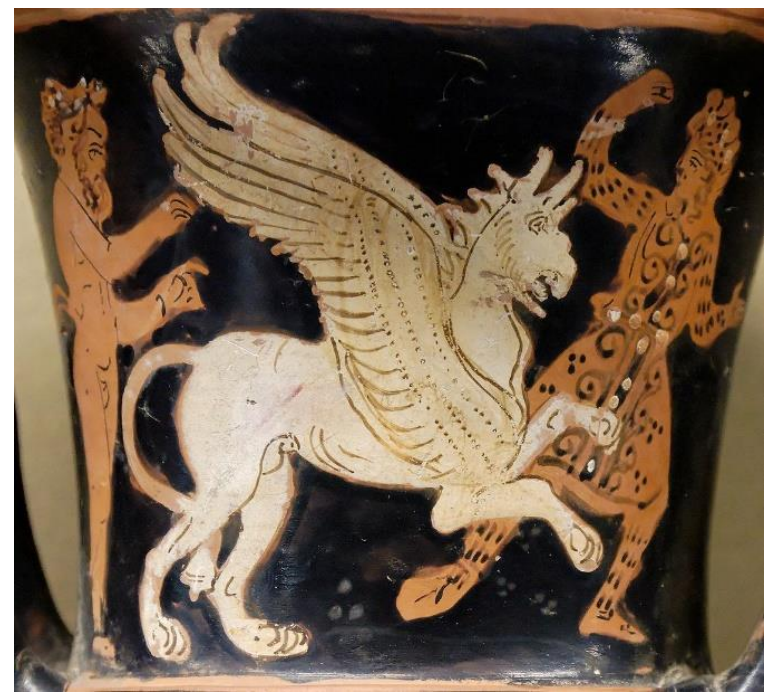

Figure 4. A satyr, a griffin and an Arimaspus. Detail from an Attic red-figure calyx-krater, ca. 375-350 BC. From Eretria (Louvre) https://en.wikipedia.org/wiki/File:Satyr_griffin_Arim aspus Louvre_CA491.jpg

Other examples are the Abarimon and the Nulo, whose feet are turned backwards relatively to their legs, with the Nulo additionally having eight toes on each foot. This also can be inspired in real malformations like the Genu recurvatum syndrome (descriptions of the malformations in Woolf \& Myrianthopoulos, 1973; Loudon, Goist \& Loudon, 1998; and Mas \& Trapote, 2003), again with an added story: that they possess wonderful velocity and cannot breathe in any climate except their own. Interestingly, the people who need their own atmosphere to breath were located by Bæton, who accompanied Alexander the Great, in the Himalaya range, where inhabitants do have particular adaptations for breathing the thin highland air, and these adaptations might have negative effects when they travel to lower regions, just like altitude sickness affects people from lower land when they travel above 2500 metres (Scheinfeldt \& Tishkoff, 2010).

A clearer example of exaggeration is the race in Albania which, according to Isigonus of
Nicæa, is born with white hair and see better in the night than in the day. This is a good description of albinism and its visual consequences (Abeshi et al., 2017), again extended from one or a few cases into a hole "race", possibly helped by the fact that some forms of albinism become frequent in particular populations, like in Puerto Rico (Witkop et al., 1990).

Another example of a particular phenomenon extended to a hole group is that of the Androgyni, a hermaphroditic people, who, Pliny adds, were "no longer considered monsters" and were in his time employed as special sex workers. Hermaphroditism is a documented phenomenon that affects very few individuals, not whole populations (Naito, 2004).

Pliny also cites people with two pupils in each eye, which is a real condition called polycoria (Jaffe \& Knie, 1952), but adds the additional stories that, according to Cicero, the glances of women with double pupils are noxious; and that, according to Apollonides, their bodies will not sink in water, perhaps a source for the trial by water later applied to witch hunt victims (Woodward, 2003).

He also mentions a few families who were exempted from public duties, including military service, because they could harmlessly walk over a burning pile of wood, which at the time seemed miraculous to the Romans but is a capacity that most humans have (Konvalinka et al., 2011).

Even the Indian women said to become pregnant only once in their lives, and to have children whose hair became white when they were born, might have some real basis because vitiligo, piebaldism, thyroid gland malfunction, tumors, and even a deficiency of Vitamin B12, can produce this effect on babies and be associated with health 
conditions affecting fertility (Giebel \& Spritz, 1991).

The Monocoli or Sciapodæ, who "have only one leg" (Figure 5), but are able to leap with surprising agility, may be inspired by cases of congenital limb defects (Swanson, 1976; Stanford University, 2020) in which the patients learn to move around by leaping on a single leg. Pliny adds that, in hot days, they lay on their backs under the shade of their feet (Figure 5), and that according to Eudoxus some men in India have feet $46 \mathrm{~cm}$ in length; while their women's feet are remarkably small.

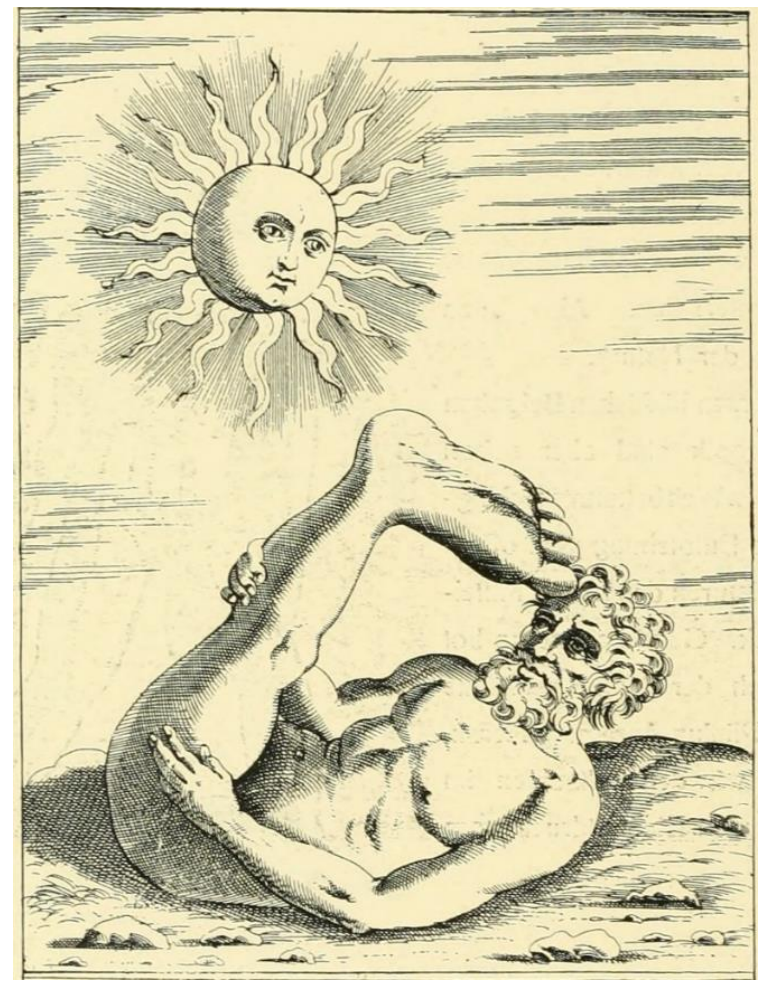

Figure 5. Sciapods from an Italian broadside of 1585 . https://nemfrog.tumblr.com/post/177391555752/anexample-of-a-human-species-called-sciapods-or

The story of men with giant feet could be based on cases of podoconiosis or elephantiasis, which produce similar symptoms of extreme limb enlargement (Schissel, Hivnor \& Elston, 1998; Davey, Tekola \& Newport, 2007); while those of the women with underdeveloped feet may represent a variety of known pathologies (see Swanson, 1976).

He also mentions the Panotti, with ears so large that they cover the whole body (Figure $6)$.

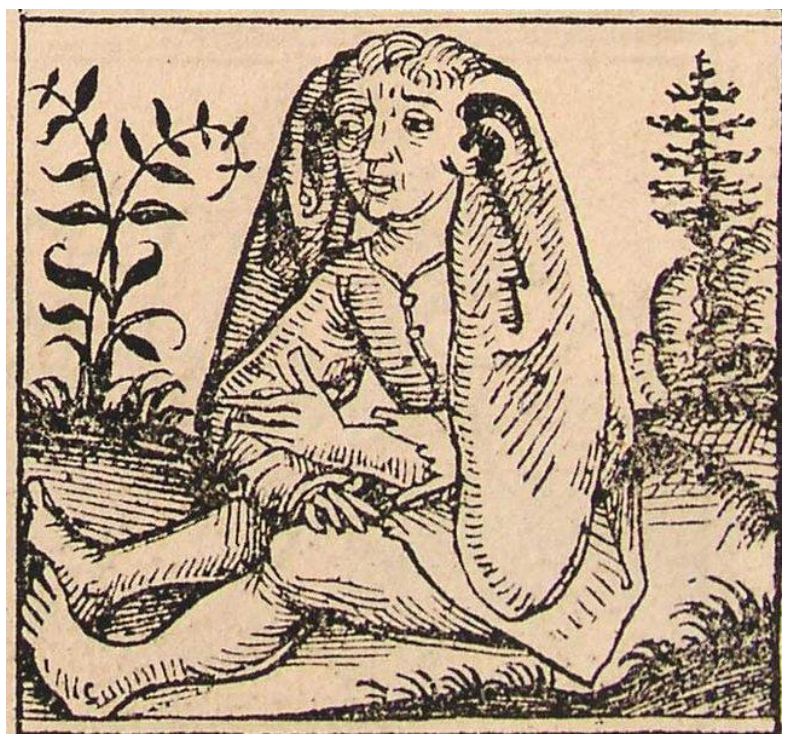

Figure 6. Pliny's Panotti, according to the Nuremberg Chronicle, by Hartmann Schedel (1440-1514).

https://commons.wikimedia.org/wiki/File:Schedel\%2 7sche Weltchronik-Large ears.jpg

There is no reported malformation that results in gigantic ears (Halsey \& Bryce, 2020), so this story is more probably based on an exaggerated report on artificially enlarged ears, like those of Ethiopia, which took place in the time of the Romans and could have been known to them thanks to geographic proximity to the empire (LaTosky, 2014). One of the most fantastical statements reproduced by Pliny describes a tribe without necks, and with eyes in their shoulders (Figure 7). 


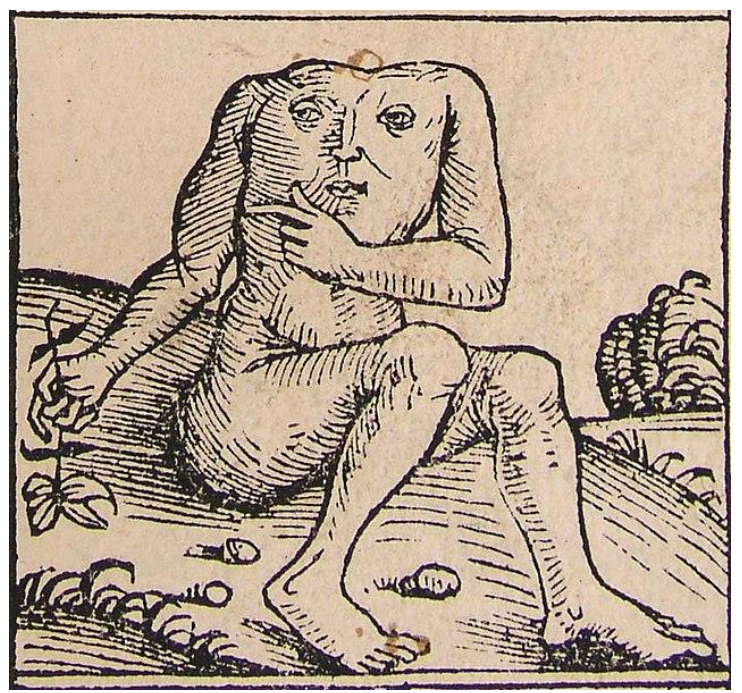

Figure 7. Pliny's headless race, according to the Nuremberg Chronicle, by Hartmann Schedel (14401514).

https://commons.wikimedia.org/wiki/File:Nuremberg _chronicles_-_Strange_People___Headless_(XIIr).jpg

There have been previous attempts to explain the origin of this description on real bases. One possibility is that it represents a mistranslation about people with face tattoos on their chests (Gevaert \& Laes, 2013); another, that it was inspired by an abnormality called anencephaly (Gevaert \& Laes, 2013), a third, parasitic twins (Aquino et al., 1997); and a fourth, that it refers to African warriors with shields, seen from a distance (Barnard, 2005; Figure 8).

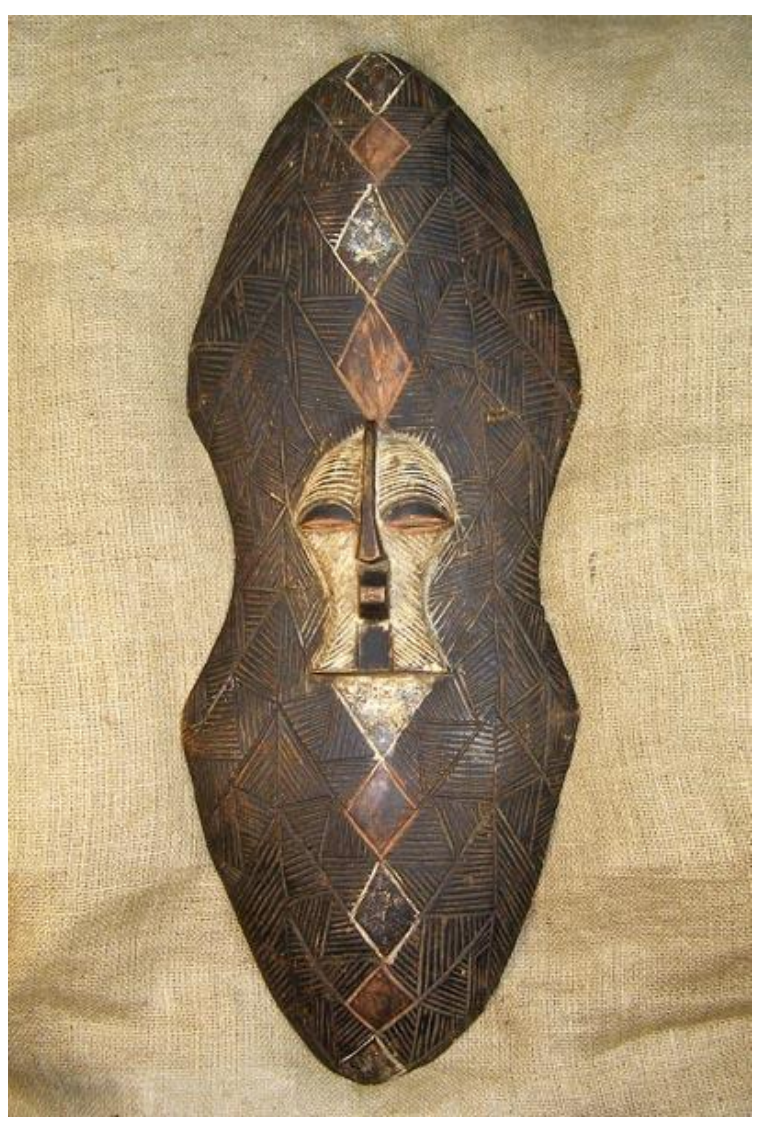

Figure 8. African shield, Songye Tribe, that, seen from a distance, might have inspired the story of men with faces on their chests, according to Barnard, 2005. Photograph:

www.tes.com/lessons/tiwYXataRGXUwg/africanshields

Pliny also mentions the human-like Satyr of Catharcludi, India, agile and swift. This region has two species that fit the description, the sacred langur (Semnopithecus entellus), and the zati macaque, Macaca radiata (Sreenivasan, Bhat \& Rajagopalan, 1986). They show some human-like behavior and are hard to catch because of their speed (Bosky, 2019), just as Pliny writes.

The story of the Scyritæ of India, without noses and with flexible feet, also sounds completely fantastic but may have been inspired by known embryogenesis defects, including arrhinia, often associated with 
other anomalies (McGlone, 2003; DeSilva \& Gill, 2013).

\section{Conclusion}

Pliny's description of the Astomi is so fantastic that it must have warned many readers about believing anything in the Natural History:

At the very extremity of India, on the eastern side, near the source of the river Ganges, there is the nation of the Astomi, a people who have no mouths; their bodies are rough and hairy, and they cover themselves with a down plucked from the leaves of trees. These people subsist only by breathing and by the odours which they inhale through the nostrils. They support themselves upon neither meat nor drink; when they go upon a long journey, they only carry with them various odoriferous roots and flowers, and wild apples, that they may not be without something to smell at. But an odour, which is a little more powerful than usual, easily destroys them.

Guarde (2012) suggested that even this obviously false report may have a real basis: it may be a misinterpretation and exaggeration of some ascetic yogi practices that include body ornamentation and fasting for days. As for Pliny himself, he expected disbelief and preemptively defended himself with two arguments: that he is mostly compiling information from respected authors (he is one of the earliest authors to cite sources instead of plagiarizing them); and that nature is so marvelous that it produces many phenomena that seem miraculous:
I shall not be content to pledge my own credit only, but shall confirm it in preference by referring to my authorities, which shall be given on all subjects of a nature to inspire doubt (Nat. Hist. 7.1).

Who, for instance, could ever believe in the existence of the Æthiopians, who had not first seen them? ... Nature, in her ingenuity, has created all these marvels in the human race, with others of a similar nature, as so many amusements to herself, though they appear miraculous to us (Nat. Hist. 7.1).

It is both unfair and dangerous to judge Pliny by our modern standards, instead of by those valid in ancient Rome (Gevaert \& Laes, 2013). While I agree that much in the Natural History is now known to be incorrect, and that the hypotheses that I present here are just hypotheses, I think that the dismissal of the book as mostly fantasy is unwarranted, and many more "fantastic tales" in the book might be found to result from exaggeration or misinterpretation of real phenomena. Even though he wrote primarily to amuse himself ("the present work was carried out during my leisure hours... and I am content with the reward of living a greater number of hours, while I am amusing myself with this"), Pliny's Natural History may still be home to much interesting and even useful information if we care to read it under this light.

\section{Acknowledgments}

I thank Guillermo Coronado for his encouragement to turn what was just an idea, into this article: like Pliny, I greatly amused myself by writing in the quiet hours of my day. I also thank Gabriela Pérez and Carolina Seas for their assistance with manuscript preparation. 


\section{Literature:}

Abeshi, A., Marinelli, C., Beccari, T., Dundar, M., Falsini, B., \& Bertelli, M. (2017). Genetic testing for ocular albinism and oculocutaneous albinism. The EuroBiotech Journal, 1(1), 80-82.

Aquino, D. B., Timmons, C., Burns, D., Lowichik, A. (1997). Craniopagus parasiticus: a case illustrating its relationship to craniopagus conjoined twinning. Pediatric Pathology and Laboratory Medicine, 17 (6): 939-44.

Barnard, H. (2005). Sire, il n'y a pas de Blemmyes: A Re-Evaluation of Historical and Archaeological Data. BAR INTERNATIONAL SERIES, 1395 , 23-40.

Bosky, K. (2019). Simian terror: Residents pay a bomb to get rid of monkeys. Deccan Herald, March 27, www.deccanherald.com/city/life-inbengaluru/residents-pay-a-bomb-toget-rid-of-monkeys-725378.html

Bostock, J., \& Riley, H.T. (Eds). (1855). The Natural History (Pliny the Elder). London, England: Taylor and Francis.

Byrne, P. J., Silver, M. M., Gilbert, J. M., Cadera, W., Tanswell, A. K., \& Reynolds, J. F. (1987). Cyclopia and congenital cytomegalovirus infection. American Journal of Medical Genetics, 28(1), 61-65.

Calabrese, P., Markowitsch, H. J., Harders, A. G., Scholz, M., \& Gehlen, W. (1995). Fornix damage and memory: A case report. Cortex, 31(3), 555-564.

Casas, A. M. M. (2008). Plinio en España: panorama general. Revista de estudios latinos: RELat, (8), 203-237.
Connie, D. (2013). The Genain Quadruplets: A 55-year follow-up of two of four monozygous sisters with schizophrenia. Schizophrenia Research 148(1-3), 186-187.

Davey, G., Tekola, F., \& Newport, M. J. (2007). Podoconiosis: non-infectious geochemical elephantiasis. Transactions of the Royal Society of Tropical Medicine and Hygiene, 101(12), 1175-1180.

De Herder, W. W. (2004). Giantism. A historical and medical view. Nederlands tijdschrift voor geneeskunde, 148(52), 2585.

DeSilva, J. M., \& Gill, S. V. (2013). Brief communication: a midtarsal (midfoot) break in the human foot. American journal of physical anthropology, 151(3), 495-499.

Fashing, P. J., Nguyen, N., Venkataraman, V. V., \& Kerby, J. T. (2014). Gelada feeding ecology in an intact ecosystem at Guassa, Ethiopia: variability over time and implications for theropith and hominin dietary evolution. American Journal of Physical Anthropology, 155(1), 1-16.

Fisher, L. 2018. What is the record for the most languages spoken by one person?. BBC Science Focus, www.sciencefocus.com/science/whatis-the-record-for-the-most-languagesspoken-by-one-person/

Gevaert, B., \& Laes, C. (2013). What's in a monster? Pliny the Elder, teratology and bodily disability. (pp. 211-230). In Brill. Laes, C., Goodey, C., \& Rose, M. L. (Eds.). (2013). Disabilities in Roman Antiquity: Disparate Bodies a capite ad calcem. Holland: Brill. 
Gibson, R. \& Morello, R. (2011). Pliny the Elder: Themes and Contexts. Leiden: Koninklijke Brill Publishers.

Giebel, L. B., \& Spritz, R. A. (1991). Mutation of the KIT (mast/stem cell growth factor receptor) protooncogene in human piebaldism. Proceedings of the National Academy of Sciences, 88(19), 8696-8699.

Gil Lascorz, F. J. (2015). De la antigua literatura de erudición al moderno relato fantástico: Plinio el Viejo y Solino, según Arthur Machen, Jorge Luis Borges e Ítalo Calvino (Doctoral dissertation, Universidad Complutense de Madrid).

Golub, 2006. What's it like to run 350 miles without stopping? A road report from the only person who knows. Easton, Pennsylvania: Runners World.

Gould; G.M \& Pyle, W. L. (2003). Anomalies and Curiosities of Medicine. New York: Kessinger Publishing.

Guarde, C. (2012). The Roots of the "Astomi" and the "Monocoli" in Ctesias and Megasthenes. Rheinisches Museum für Philologie, 155 (2): 215218.

Halsey, L. G., \& Bryce, C. M. (2020). Are humans evolved specialists for running in the heat? Man vs. horse races provide empirical insights. Experimental Physiology.

Healy, J. F. (1999). Pliny the Elder on science and technology. Clarendon Press.

Isager, J. (2013). Pliny on art and society: the Elder Pliny's chapters on the history of art. Routledge.
Jaffe, N. S., \& Knie, P. (1952). True polycoria. American Journal of Ophthalmology, 35(2), 253-255.

Johns Hopkins University. (2020). The Growing Child: 3-Year-Olds, Baltimore, Maryland. www.hopkinsmedicine.org/health/wel lness-and-prevention/the-growingchild-3yearolds

Konvalinka, I., Xygalatas, D., Bulbulia, J., Schjødt, U., Jegind $\varnothing$, E. M., Wallot, S., ... \& Roepstorff, A. (2011). Synchronized arousal between performers and related spectators in a fire-walking ritual. Proceedings of the National Academy of Sciences, 108(20), 8514-8519.

LaTosky, S. (2014). Images of Mursi women and the realities they reveal and conceal. p. 121-146. In Girke, $F$. Ethiopian images of self and other. Nederland, Halle: Zentrum für Interkulturelle Regionalstudien.

Loudon, J. K., Goist, H. L., \& Loudon, K. L. (1998). Genu recurvatum syndrome. Journal of Orthopaedic \& Sports Physical Therapy, 27(5), 361-367.

Mas, M. R., \& Trapote, L. G. (2003). El pie en crecimiento. Revista española de reumatología: Órgano Oficial de la Sociedad Española de Reumatología, 30(9), 516-535.

McGlone, L. (2003). Congenital arhinia. Journal of paediatrics and child health, 39(6), 474-476.

Migliano, A. B., Romero, I. G., Metspalu, M., Leavesley, M., Pagani, L., Antao, T., ... \& Hudjashov, G. (2013). Evolution of the pygmy phenotype: Evidence of positive selection from 
genome-wide scans in African, Asian, and Melanesian pygmies. Human Biology, 85(1-3), 251-284.

Naito, K. (2004). True hermaphroditism. Nihon Rinsho. Japanese journal of clinical medicine, 62(2), 300-304.

Nordt, C. A., \& DiVasta, A. D. (2008). Gynecomastia in adolescents. Current opinion in pediatrics, 20(4), 375-382.

Norris, H. J., \& Taylor, H. B. (1969). Virilization associated with cystic granulosa tumors. Obstetrics \& Gynecology, 34(5), 629-635.

Organising Committee for the Olympic Games. (2004). Weightlifting Official Results Book. Athens: Official Report of the XXVIII Olympiad.

Poulakakis, N., Mylonas, M., Lymberakis, P., \& Fassoulas, C. (2002). Origin and taxonomy of the fossil elephants of the island of Crete (Greece): problems and perspectives. Palaeogeography, Palaeoclimatology, Palaeoecology, 186(1-2), 163-183.

Rosenthal, M. S. (2010). A preventive ethics approach to IVF in the age of octuplets. Fertility and sterility, 93(2), 339-340.

Sacks, O. (2006). The Man Who Mistook His Wife for a Hat and Other Clinical Tales. New York: Touchstone/Simon \& Schuster.

Scheinfeldt, L. B., \& Tishkoff, S. A. (2010). Living the high life: high-altitude adaptation. Genome biology, 11(9), 13.

Schissel, D. J., Hivnor, C., \& Elston, D. M. (1998). Elephantiasis nostras verrucosa. Cutis, 62(2), 77-80.
Sreenivasan, M. A., Bhat, H. R., \& Rajagopalan, P. K. (1986). The epizootics of Kyasanur Forest disease in wild monkeys during 1964 to 1973. Transactions of the Royal Society of Tropical Medicine and Hygiene, 80(5), 810-814.

Stanford University. (2020). Congenital Limb Defect in Children. Lucile Packard Children's Hospital, Stanford, California:

www.stanfordchildrens.org/en/topic/d efault?id=congenital-limb-defects-90$\mathrm{P} 02752$.

Stulp, G., \& Barrett, L. (2016). Evolutionary perspectives on human height variation. Biological Reviews, 91(1), 206-234.

Swanson, A. B. (1976). A classification for congenital limb malformations. Journal of Hand Surgery, 1(1), 8-22.

Treffert, D. A. (2009). The savant syndrome: an extraordinary condition. A synopsis: past, present, future. Philosophical Transactions of the Royal Society B: Biological Sciences, 364(1522), 1351-1357.

Viscardi, P., Hollinshead, A., MacFarlane, R., \& Moffatt, J. (2014). Mermaids uncovered. Journal of Museum Ethnography, (27), 98-116.

Witkop, C. J., Nuñez, M. B., Rao, G. H., Gaudier, F., Summers, C. G., Shanahan, F., ... \& King, R. A. (1990). Albinism and Hermansky-Pudlak syndrome in Puerto Rico. Boletin de la Asociacion Medica de Puerto Rico, 82(8), 333-339.

Woodward, W. W. (2003). New England's Other Witch-Hunt: The Hartford 
Witch-Hunt of the 1660s and Changing Patterns in Witchcraft Prosecution. OAH Magazine of History, 17(4), 16-20.

Woolf, C. M., \& Myrianthopoulos, N. C. (1973). Polydactyly in American negroes and whites. American journal of human genetics, 25(4), 397.

Yale University. (2008). Willard Wigan Artist. New Haven, Connecticut: The Yale Center for Dyslexia \& Creativity, http://dyslexia.yale.edu/story/willardwigan/ 